\title{
Paleomagnetic directional groups and paleointensity from the flood basalt in the Tarim large igneous province: implications for eruption frequency
}

\author{
Yoichi Usui ${ }^{1 *}$ (D) and Wei Tian²
}

\begin{abstract}
We present paleomagnetic secular variation and paleointensity from the Early Permian Tarim large igneous province, NW China. The studied sections comprise a total of $\sim 400 \mathrm{~m}$ of basaltic flows. Paleomagnetic directions were determined for 11 flows. Four successive flows with a cumulative thickness of $\sim 150 \mathrm{~m}$ showed a statistically identical paleomagnetic direction. Assuming a paleosecular variation speed similar to that of the present day, the $\sim 150-\mathrm{m}$-thick basalt was estimated to have erupted within the past few centuries. Paleointensity experiments were performed on both whole-rock and single plagioclase samples. Although alterations during the experiment and/or weak remanence degraded the data quality, the flows with the same paleomagnetic direction revealed similar paleointensity estimates, supporting the hypothesis that the eruption of these flows was rapid. More generally, flows from the Lower Kupukuziman Formation seem to record lower paleointensity compared to flows from the overlying Kaipaizileike Formation.
\end{abstract}

Keywords: Large igneous province, Tarim block, Superchron, Paleosecular variation, Single plagioclase paleointensity

\section{Background}

The activity of large igneous provinces (LIPs), especially continental flood basalts, can have significant effects on the global climate and the chemistry of the hydrosphere, potentially accounting for some of the major extinctions (e.g., Wignall 2001; Bond and Wignall 2014). The proposed mechanisms involve the emission of volatiles such as $\mathrm{H}_{2} \mathrm{~S}, \mathrm{SO}_{2}, \mathrm{HCl}, \mathrm{HF}$, and $\mathrm{CO}_{2}$ into the atmosphere, leading to ocean acidification, global temperature perturbation, and ozone depletion. A key parameter in determining the environmental and biological consequences of the activity of LIPs is the eruption rate. For some flood basalts, such as the Deccan traps and the Siberian traps, pulses of large and rapid eruptions with volumes

\footnotetext{
*Correspondence: yoichi@jamstec.go.jp

${ }^{1}$ Department of Deep Earth Structure and Dynamics Research, Japan Agency for Marine-Earth Science and Technology, 2-15 Natsushima-cho, Yokosuka 2370061, Japan

Full list of author information is available at the end of the article
}

of thousands of $\mathrm{km}^{3}$ and fluxes of $\sim 100 \mathrm{~km}^{3} /$ year are proposed, mainly on the basis of paleomagnetic analysis (Chenet et al. 2008; Pavlov et al. 2011; Courtillot and Fluteau 2014).

A large volume of Early Permian igneous rocks in the Tarim basin has recently been recognized as an LIP (Yang et al. 2006; Tian et al. 2010), following the definition of Bryan and Ernst (2008). Although the bulk of the Tarim LIP (TLIP) is covered by the Taklimakan desert, geophysical and drill core data, together with outcrop investigations along the edge of the desert, indicate that the TLIP covers an area $>300,000 \mathrm{~km}^{2}$ with an estimated volume in excess of $300,000 \mathrm{~km}^{3}$, of which over $80 \%$ is occupied by flood basalt (Yang et al. 2005; Tian et al. 2010).

The eruption frequency of the TLIP flood basalt has been investigated by radiometric dating. SHRIMP $\mathrm{U}-\mathrm{Pb}$ ages were reported for a $\sim 1500$-m-thick section including 500-m-thick basaltic flows (Yu et al. 2011). The uppermost and the lowermost flows revealed statistically identical ages $(289.5 \pm 2.0$ and $288.0 \pm 2.0 \mathrm{Ma}$, 
respectively, with errors indicating $2 \sigma$ ) in the studied section (Yu et al. 2011). These ages were confirmed by more recent measurements of ${ }^{40} \mathrm{Ar} /{ }^{39} \mathrm{Ar}$ plateau ages obtained from nearby sites $(287.3 \pm 2.0$ and $287.9 \pm 3.1 \mathrm{Ma}$; Wei et al. 2014). Together, the emplacement duration for the $\sim 500$-m-thick basalt can be constrained to less than $\sim 6$ Myr. If the basalt activity spans $\sim 6 \mathrm{Myr}$, the instantaneous volcanic flux would be on the order of $0.1 \mathrm{~km}^{3} /$ year or less, being too small to have a significant environmental impact. However, the uncertainty in the radiometric dating cannot exclude the possibility that the basalt activity is much shorter than $\sim 6 \mathrm{Myr}$.

Paleomagnetic secular variation (PSV) analysis has been employed to constrain the eruption frequency down to the millennium or century timescale, and to identify the eruption pulses in some LIPs (Makinen et al. 1985; Riisager et al. 2003; Knight et al. 2004; Chenet et al. 2008; Pavlov et al. 2011; Courtillot and Fluteau 2014). The geomagnetic field exhibits secular variation, both in direction and intensity, in timescales of decades to a century. On the other hand, in many LIPs, successive lava flows yield statistically identical paleomagnetic directions. Such directions are regarded to form a directional group. The lava flows recording a directional group must erupt and cool rapidly relative to the PSV speed. Holocene paleomagnetic data revealed that the mean speed of the geomagnetic directional change is $2-7 \%$ century (Gallet et al. 2002; Hagstrum and Campion 2002; Chenet et al. 2008; Courtillot and Fluteau 2014). Using paleomagnetic directions with uncertainties less than $10^{\circ}$, Chenet et al. (2008) argued that the lava flows in each directional group in the Deccan trap were emplaced within roughly 100 years. In contrast, the absence of clear directional groups in the Paraná volcanic province has been taken as a sign of steady volcanic activity without a particular pulse (Dodd et al. 2015). The geomagnetic intensity change on this timescale is not as well-constrained. Nonetheless, a geomagnetic field model based on historical data (Jackson et al. 2000) and recent archaeomagnetic data (Shaar et al. 2015) shows that the maximum intensity change per decade is $\sim 5 \%$.

A previous paleomagnetic study for the TLIP reported a positive fold test, indicating that the basalt retains primary remanence (Sharps et al. 1989). All examined flows showed reversed paleomagnetic directions; this is consistent with the age of the basalt ( $288 \mathrm{Ma})$, which falls in the middle of the Permo-Carboniferous reversed Superchron (PCRS). However, the study focused on establishing the average direction, and the PSV record was not discussed. In this report, we acquire new paleodirectional and paleointensity data from the TLIP basalt to constrain the eruption frequency.

\section{Geology and sampling}

We studied outcrops at the Sishichang, Kaipaizileike, and Yingan sections (Figs. 1 and 2). These sections were close to the sections from which radiometric ages have been obtained, as introduced earlier (Yu et al. 2011; Wei et al. 2014). These sections can be easily correlated to each other using satellite images and several key beds ( $\mathrm{Yu}$ et al. 2011). Two packages of basalt sequences occur in fluvial siliciclastic sedimentary rocks. They are assigned to the Lower Kupukuziman Formation and Kaipaizileike Formation (Fig. 2). A large-scale structural discontinuity exists between Yingan and the other sections. The Yingan section investigated in this study is also close to the Yingan section studied by Sharps et al. (1989). The Sishichang and Kaipaizileike sections belong to the structural extension from the Subashi section of Sharps et al. (1989).

Yu et al. (2011) described two basaltic horizons and six basaltic horizons in the Kupukuziman and Kaipaizileike Formations, respectively. We sampled two basaltic horizons (KP1 and KP2) for the Kupukuziman Formation and five horizons (KZ1-KZ5) for the Kaipaizileike Formation (Fig. 2). KZ4 is distinctive in its andesitic character, corresponding to BU7 of Yu et al. (2011). In addition, based on detailed field observations, we distinguish basaltic flows separated by siliciclastic sediment within some of the basaltic horizons. In all, we sampled 11 basaltic flows (Fig. 2).

We collected standard field-drilled cores of the basaltic flows. Core orientations were taken with a Sun Compass using a Pomeroy orientation device. We sampled three flows from the Kupukuziman Formation and eight flows from the Kaipaizileike Formation. Site locations were recorded using a GPS. Basalt lava flows form a topographic high. With a moderate degree of bedding tilt $\left(30^{\circ}-50^{\circ}\right)$, the top and bottom of the flows are generally weathered or covered. Consequently, we sampled what we believe to be the middle part of each flow. Except for andesitic KZ4, samples are plagioclase-phyric with abundant euhedral plagioclase crystals less than $1 \mathrm{~mm}$ in length. Some flows occasionally contain large $(>2 \mathrm{~mm})$ plagioclase crystals. The large crystals often exhibit irregular shapes, and they may be xenocrysts (Fig. 3).

\section{Magnetic mineralogy}

The temperature dependence of low-field magnetic susceptibility, $\kappa(T)$, was measured using an AGICO KLY-4 kappabridge susceptibility meter equipped with a hightemperature furnace. Measurements were conducted in ambient air. Each site except for KZ4 yielded an apparent Curie point at $450-500{ }^{\circ} \mathrm{C}$ upon heating, indicating lowTi titanomagnetite in these samples (Fig. 4). In contrast, 


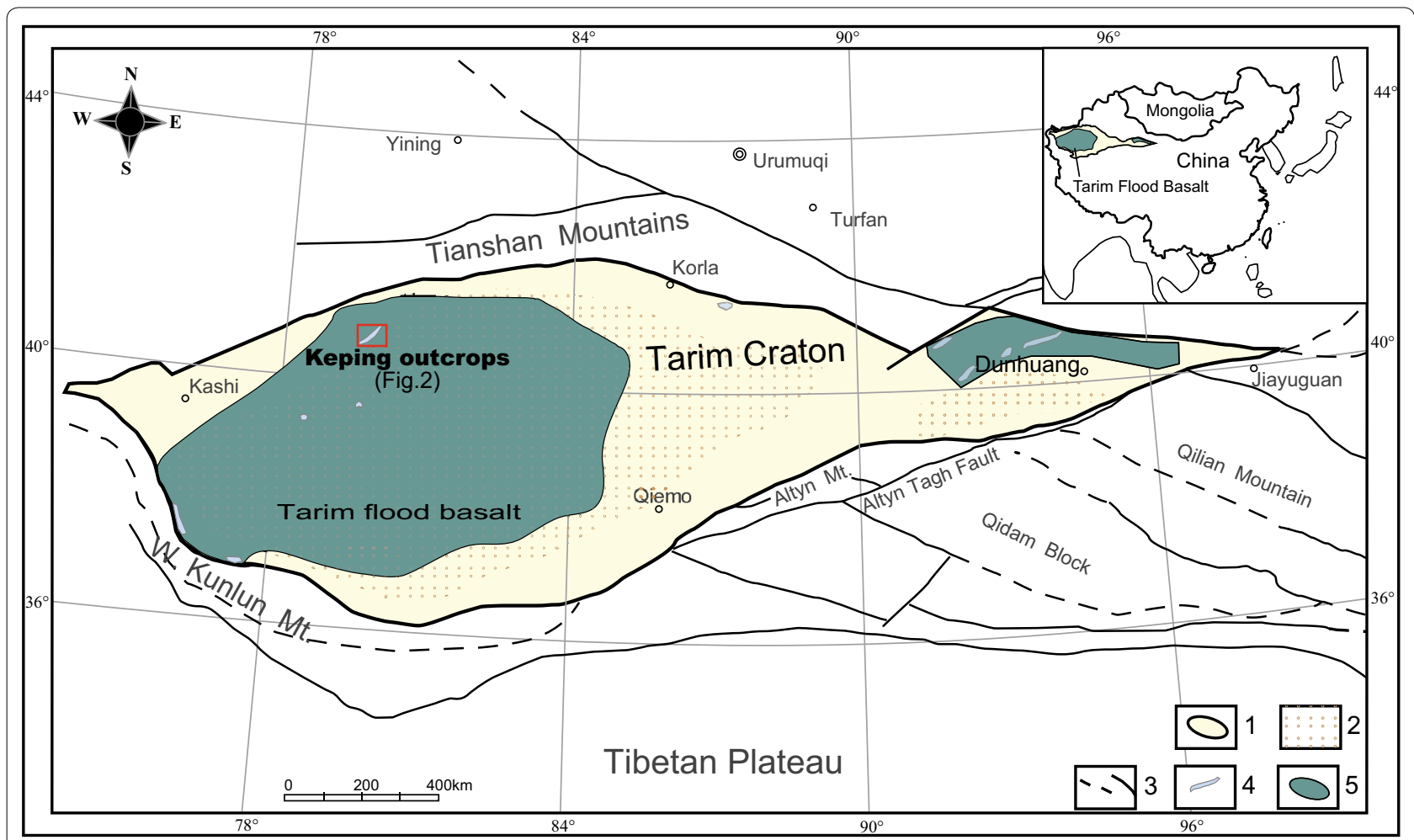

Fig. 1 Sketch of the geological map of the Tarim Flood Basalt Province (after Chen et al. 2014). Inset shows its geographical location in NW China. 1 Tarim Craton; 2 area covered by desert; 3 major faults; 4 Basalt outcrop; 5 estimated basalt area

the sample KZ4 revealed near-reversible curves, with an apparent Curie temperature at $\sim 590{ }^{\circ} \mathrm{C}$, indicating that near-stoichiometric magnetite is the main magnetic mineral in this sample. Some samples exhibit additional Curie points at $\sim 400$ and $\sim 550{ }^{\circ} \mathrm{C}$ (Fig. 4). When heated in Ar, the $\sim 550^{\circ} \mathrm{C}$ signal was significantly suppressed. We interpret this as a reflection of magnetite formation due to oxidation from heating in air. The cooling curves are always below the heating curves, indicating significant alteration due to heating. The apparent Curie point for the cooling curves is at either $\sim 550$ or $\sim 400{ }^{\circ} \mathrm{C}$. Again, heating in Ar often (but not always) resulted in the single Curie point for the cooling curves at $\sim 400{ }^{\circ} \mathrm{C}$. We interpret this as re-mixing of magnetite lamellar in titanomagnetite present before heating.

Magnetic hysteresis parameters (coercivity $H_{c}$; coercivity of remanence $H_{\mathrm{cr}}$; saturation remanence $M_{\mathrm{r}}$; and saturation magnetization $M_{\mathrm{s}}$ ) were measured using a Model 3900 Princeton Measurement Corporation vibrating sample magnetometer for bulk rock samples and a Model 2900 alternating gradient magnetometer at the Geological Survey Japan. The hysteresis parameters were analyzed on a Day plot (Day et al. 1977; Dunlop 2002). The data indicate a pseudo-single domain (PSD) magnetic carrier in all samples (Table 1; Fig. 5).

\section{Paleomagnetic methods}

\section{Paleomagnetic direction}

Step-wise demagnetization was conducted using a Model TDS-1 paleomagnetic oven (Natsuhara Giken) and a Model DEM-95AF demagnetizer with two axis tumbling (Natsuhara Giken). Magnetic remanence was measured using a Model ASPIN spinner magnetometer (Natsuhara Giken). All paleomagnetic measurements were carried out in the magnetically shielded room at JAMSTEC Yokosuka HQ. The demagnetization data were analyzed using principal component analysis (Kirschvink 1980). Site-mean directions were calculated using Fisher (1953) statistics. Analysis was done using PuffinPlot software version 1.03 (Lurcock and Wilson 2012). For each section, the average bedding attitude of nearby siliciclastic sediment was used for tilt corrections.

The directional results were analyzed to detect any occurrence of directional groups. A series of criteria following Chenet et al. (2008) was used. Successive flows were considered to be in the same directional group as the corresponding site-mean direction within a threshold angular distance $\sigma$ from the overall mean direction for the corresponding site-mean directions, where $\sigma$ is the root-mean-square of the corresponding $\alpha_{95}$. If $\sigma$ was 


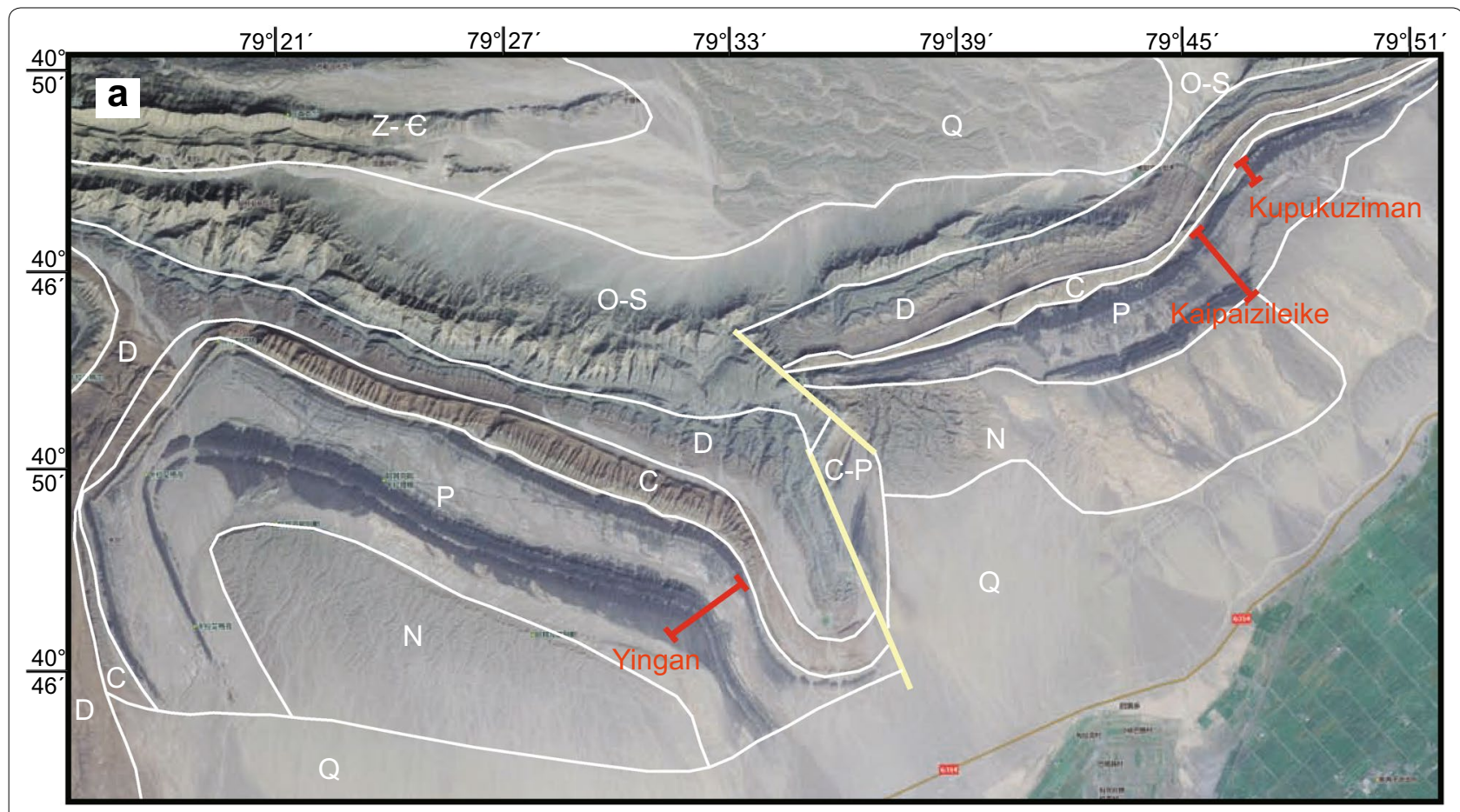

b
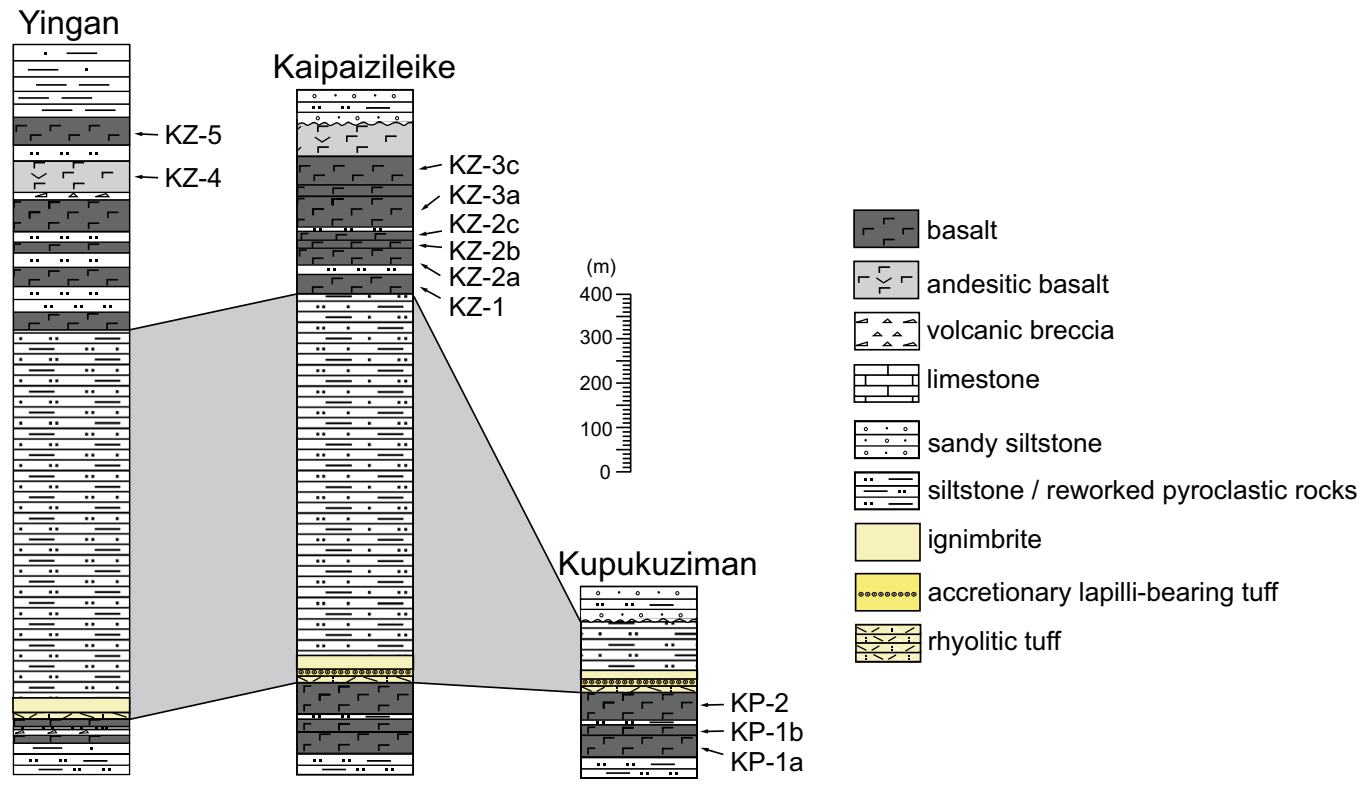

Fig. 2 a Satellite image showing the locations of Yingan, Kaipaizileike, and Kupukuziman sections (adopted from Yu et al. 2011). b Stratigraphic columns of Yingan (modified from Yu et al. 2011), Kaipaizileike and Kupukuziman (this study)

larger than $10^{\circ}$, the results were judged to be unconstrained and discarded.

\section{Paleointensity}

The paleointensity experiments were performed on the 1-in. cores or unoriented plagioclase phenocrysts. The plagioclase crystals were handpicked from the crushed cores and checked under a stereoscopic microscope (Nikon SMZ1000) for any surface contamination. No distinction of potential xenocrysts was made. The IZZI protocol of the Thellier-Coe paleointensity method (Thellier and Thellier 1959; Coe 1967; Coe et al. 1978; Tauxe and 


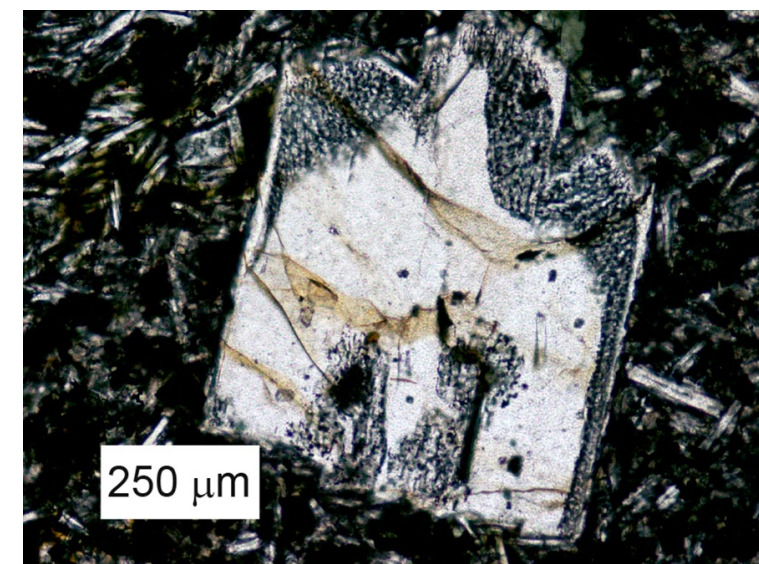

Fig. 3 Thin section image of large plagioclase crystals. White scale bar is $250 \mu \mathrm{m}$

Staudigel 2004) was used. The sample was successively demagnetized in zero-field heating ( $Z$ step) and remagnetized in in-field heating (I step). The $\mathrm{Z}$ and I steps are combined in an alternating way. Laboratory alteration of magnetic minerals was checked by partial thermoremanence (pTRM) where previous in-field heating was repeated at every second temperature step. Heating was done using the oven TDS-1 for 1-inch cores and the custom-made infrared heating device (Usui et al. 2015) for plagioclase crystals. The laboratory magnetizing field intensity was set to range from 20 to $40 \mu \mathrm{T}$. The results were analyzed using the ThellierTool software version 2.0 (Leonhardt et al. 2004). Paleointensity estimates were obtained from a least-squares linear fit to a segment of pTRM gained versus NRM lost plot (the Arai plot; Arai 1963). The criteria for the successful trials were as follows: (1) Five or more successive steps should define the linear segment $(N \geq 5)$; (2) The standard deviation of the linear fit should be smaller than 0.15 of the slope $(\beta \leq 0.15)$; (3) The linear segment should represent more than $30 \%$ of the original NRM intensity $(f \geq 0.3)$; (4) the directional data of the corresponding $\mathrm{Z}$ steps should define an origin-trending demagnetization with maximum angular deviation (Kirschvink 1980) less than $15^{\circ}$
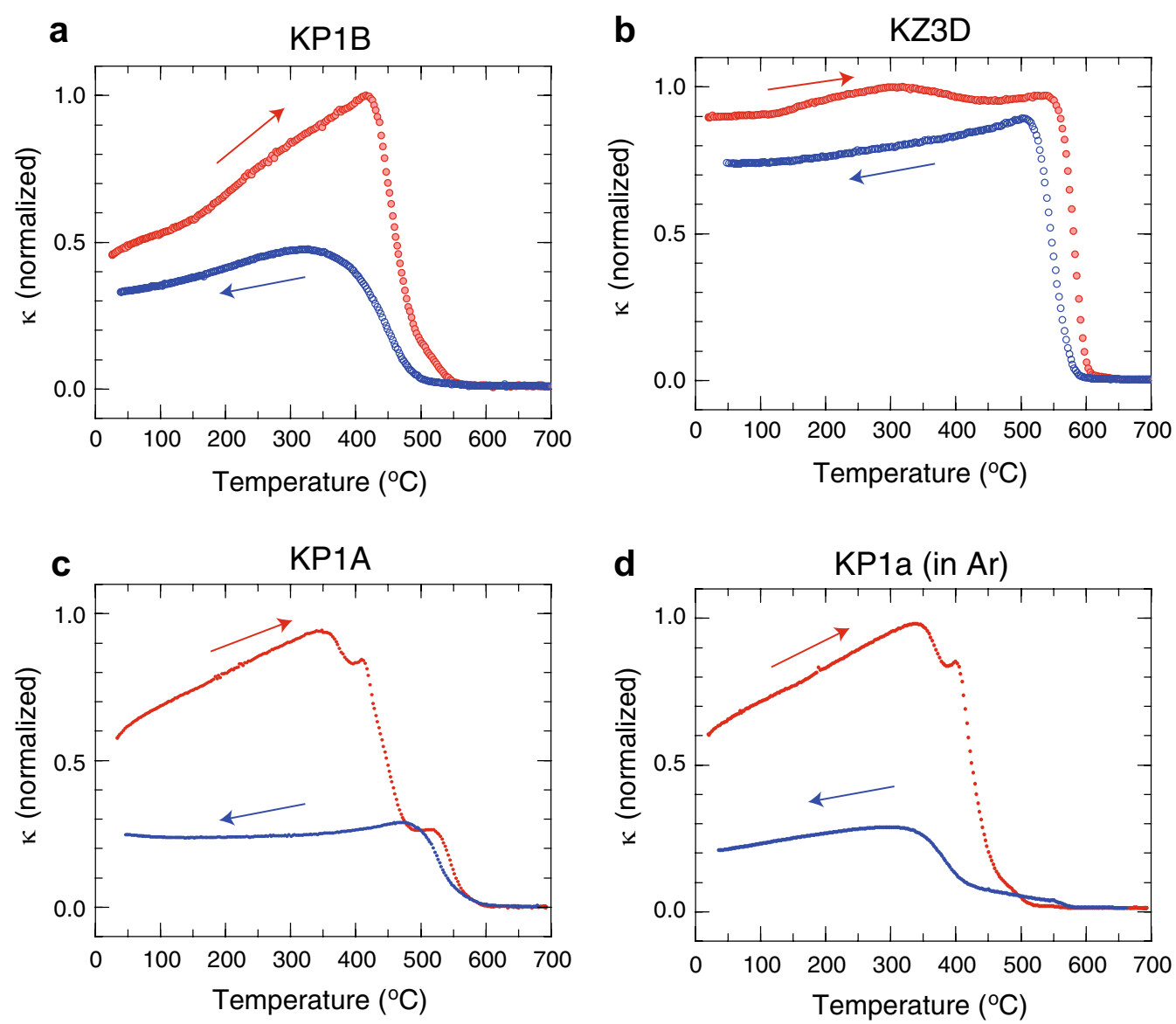

Fig. 4 Thermomagnetic curves of magnetic susceptibility. Red filled symbols represent heating, and blue open symbols represent cooling. Rock magnetic data. a Sample with single Curie point, heating in air. b Sample with a Curie point suggestive of magnetite with near-reversible curves, heating in air. c Sample with three Curie points, heating in air. d Same sample as (c) heated in Ar showing two Curie points 
Table 1 Summary of hysteresis parameters and median destructive field of NRM (MDF_NRM)

\begin{tabular}{llll}
\hline Site & Mrs/Ms & Hcr/Hc & MDF_NRM $(\mathbf{m T})$ \\
\hline KP1a & 0.099 & 2.62 & 70 \\
KP1b & 0.435 & 1.77 & 45 \\
KP2 & 0.062 & 2.73 & 30 \\
KZ1 & 0.096 & 2.78 & 40 \\
KZ2a & 0.069 & 2.41 & 20 \\
KZ2b & 0.047 & 3.13 & 15 \\
KZ2c & 0.061 & 2.68 & 15 \\
KZ3 & 0.062 & 3.19 & 20 \\
KZ3c & 0.174 & 1.87 & 60 \\
KZ4 & 0.154 & 2.67 & 40 \\
KZ5 & 0.250 & 1.68 & 20 \\
\hline
\end{tabular}

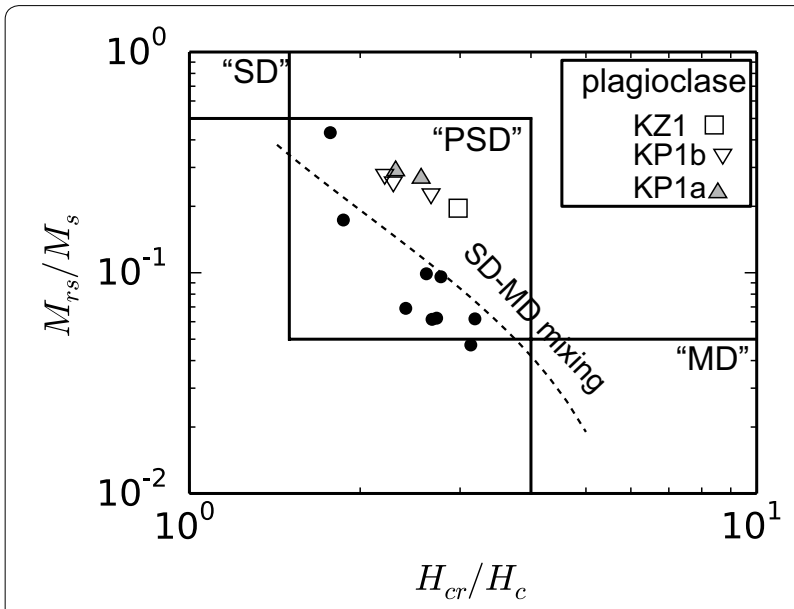

Fig. 5 Hysteresis parameters on a Day plot. Filled circles represent bulk samples, and other symbols represent plagioclase crystals. The combination of the parameters defines regions corresponding to "single-domain (SD)," "pseudo-single domain (PSD)," and "multidomain $(\mathrm{MD})$ " characters, as outlined on the plot. Dashed lines are single-domain-multi-domain mixing curve after Dunlop (2002)

$(\mathrm{MAD}<0.15)$, and (5) The pTRM check should be within $7 \%$ of the corresponding pTRM $(\delta(\mathrm{CK}) \leq 0.07)$. These are similar to the default "Class B" criteria of ThellierTool (Leonhardt et al. 2004). As discussed below, the paleointensity experiments were rather unsuccessful, and no "Class A" data (Leonhardt et al. 2004) were obtained.

\section{Results}

\section{Paleomagnetic direction}

Two pilot specimens for each basaltic flow were analyzed in detailed thermal and AF demagnetization. For all flows, both methods revealed similar characteristic directions after the removal of a low stability component by $\sim 10 \mathrm{mT}$
AF treatment or $200{ }^{\circ} \mathrm{C}$ thermal treatment (Fig. 6). Stability against AF treatment is different among sites. The unblocking temperature is $400-450{ }^{\circ} \mathrm{C}$ except for the sample $\mathrm{KZ} 4$, and no correlation with AF stability or the hysteresis parameter was obvious. Therefore, the stability against AF treatment is likely to reflect differences in grain size rather than mineralogy, which in turn may be related to the local cooling rate. The sample $\mathrm{KZ} 4$ shows unblocking at $\sim 590^{\circ} \mathrm{C}$. The unblocking temperature data are consistent with the major Curie point estimated from thermomagnetic results.

After the pilot specimens, the remaining specimens were treated by AF demagnetization. Table 2 summarizes the directional results. All of the 11 flows examined revealed well-defined site-mean directions with $\alpha_{95}<10^{\circ}$ (Fig. 7). Only reversed polarity was detected, and the directions were generally consistent with the results of Sharps et al. (1989). In particular, our data from the Yingan section were very close to the mean direction reported by Sharps et al. (1989) for the Yingan section. The limited number of sites in the Yingan section in our dataset precludes formal fold testing; however, the close agreement with the Sharps et al. (1989) direction supports that our directions also predate the major tilting.

The first four flows (KP1a-KZ1) revealed site-mean directions statistically distinct from each other. The following four flows (KZ2a-KZ3a), which span $\sim 150 \mathrm{~m}$ of stratigraphy, exhibit statistically identical site-mean directions. On the basis of the criteria of Chenet et al. (2008), directions from these flows form a directional group. The site-mean directions of the remaining three flows are again distinct (Fig. 4). The tight clustering of the site-mean directions in the directional group raises the question of potential remagnetization. We feel that this is not the case, because (1) a flow (KZ3c) very close to the flows showing the directional group exhibits a statistically different direction from the directional group; (2) there are no obvious rock magnetic properties specific to the directional group (Tables 2, 3) field as well as microscope observations did not detect any sign suggesting further alteration in the directional group.

\section{Paleointensity}

The 1-in. core specimens generally suffer from laboratory alteration as indicated by failure in the pTRM checks (Fig. 8). An exception was the sample KZ4, where some specimens pass the selection criteria. This flow gives a paleointensity of 36-45 $\mu \mathrm{T}$ (Fig. 8).

Single plagioclase crystals revealed successful results from flows KP1a, KP1b, KZ2a, and KZ4. The presence of anomalously large plagioclase crystals, which may be xenocrysts, is the main reason for the success of those sites while other sites are not. Even in those sites, the 
a
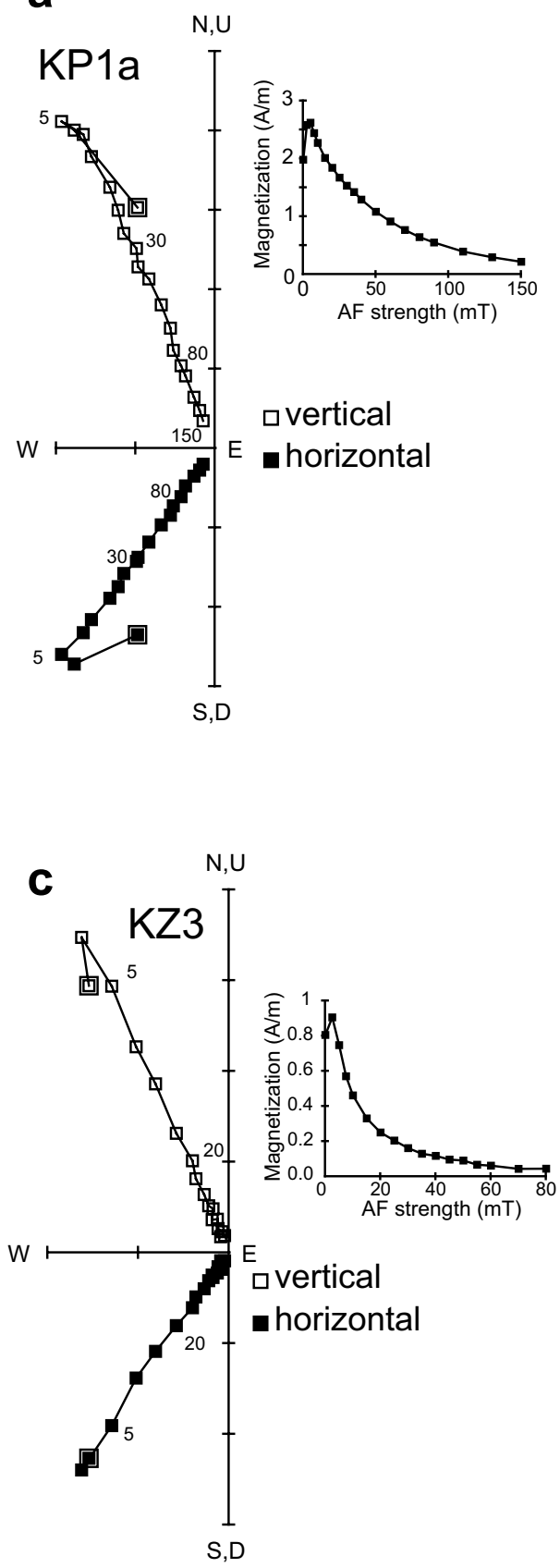

b

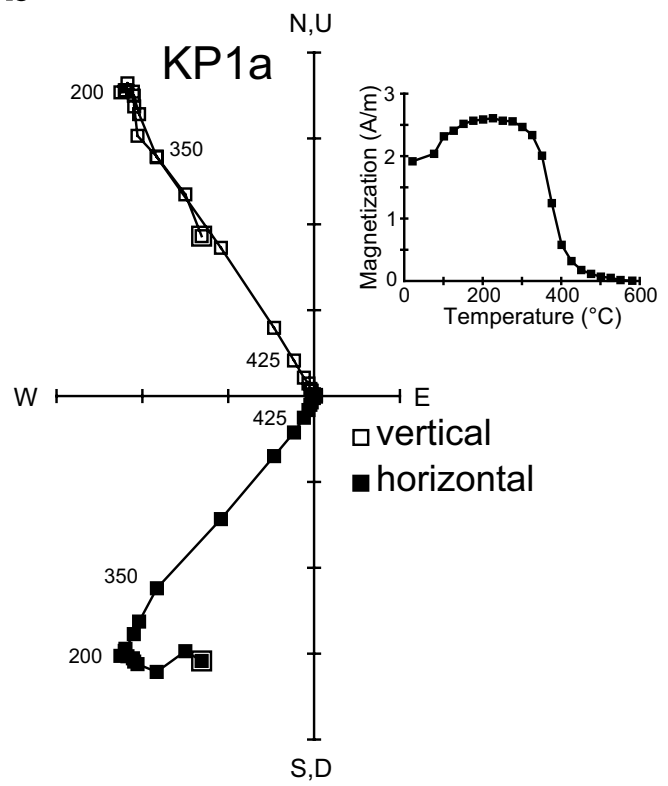

d

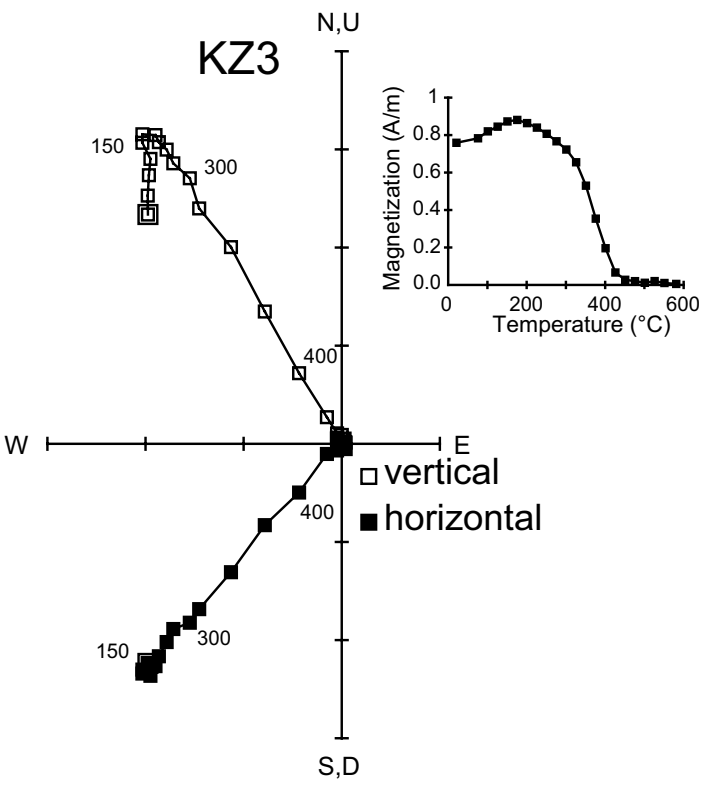

Fig. 6 Representative demagnetization behavior of tilt-corrected paleomagnetic directions in orthogonal vector plots and magnetization versus demagnetization step plots. a AF demagnetization of the sample KP1a. b Thermal demagnetization of the sample KP1a. C AF demagnetization of the sample KZ3. $\mathbf{d}$ Thermal demagnetization of the sample KZ3

success rate was not higher than $30 \%$, and a much larger number of crystals simply had a remanence too weak to be measured. Typical failure includes strong curvature in the Arai plot and scattered demagnetization as well as failure in the pTRM checks. The successful crystals from flows KP1a and KP1b revealed a paleointensity of 7-17 $\mu \mathrm{T}$, while KZ2a and KZ4 revealed a paleointensity of 38 and $16 \mu \mathrm{T}$, respectively (Fig. 8). 
Table 2 Summary of the directional results

\begin{tabular}{|c|c|c|c|c|c|c|c|c|c|c|c|}
\hline Site & Longitude $\left({ }^{\circ}\right)$ & Latitude $\left({ }^{\circ}\right)$ & Bedding strike & Bedding dip & $n$ & Dec. $\left({ }^{\circ}\right)$ & Inc. $\left(^{\circ}\right)$ & Dec_c $\left(^{\circ}\right)$ & Inc_c $\left({ }^{\circ}\right)$ & $a_{95}\left(^{\circ}\right)$ & $k$ \\
\hline KP1a & 79.772 & 40.797 & 38 & 26 & 8 & 190.9 & -44.0 & 217.7 & -53.7 & 2.2 & 787 \\
\hline KP1b & 79.775 & 40.798 & 38 & 26 & 5 & 213.4 & -35.7 & 230.2 & -32.4 & 2.5 & 962 \\
\hline KP2 & 79.777 & 40.797 & 38 & 26 & 8 & 213.1 & -61.9 & 255.0 & -54.0 & 4.2 & 175 \\
\hline KZ1 & 79.770 & 40.762 & 56 & 26 & 4 & 182.4 & -38.7 & 203.9 & -56.8 & 4.9 & 349 \\
\hline KZ2a & 79.772 & 40.760 & 56 & 26 & 4 & 191.6 & -35.8 & 212.4 & -50.8 & 7.2 & 164 \\
\hline $\mathrm{KZZ} 2 \mathrm{~b}$ & 79.772 & 40.759 & 56 & 26 & 7 & 190.6 & -37.9 & 212.9 & -53.0 & 2.9 & 422 \\
\hline $\mathrm{KZZC}$ & 79.774 & 40.760 & 56 & 26 & 5 & 190.8 & -37.2 & 214.0 & -55.4 & 4.8 & 256 \\
\hline KZ3a & 79.774 & 40.759 & 56 & 26 & 7 & 194.0 & -40.2 & 218.8 & -53.6 & 2.2 & 787 \\
\hline KZ3C & 79.774 & 40.758 & 56 & 26 & 6 & 198.9 & -32.0 & 220.8 & -41.2 & 2.5 & 731 \\
\hline KZ4 & 79.472 & 40.665 & 100 & 30 & 4 & 222.0 & -10.6 & 229.6 & -35.2 & 7.4 & 156 \\
\hline KZ5 & 79.523 & 40.650 & 100 & 30 & 5 & 209.4 & -31.2 & 222.8 & -58.5 & 8.7 & 77.5 \\
\hline
\end{tabular}

Latitude and longitude are GPS latitude of the site. Bedding strike and dip are expressed in dip to right of strike format

$n$ specimen number, Dec. and Inc. in situ declination and inclination, Dec_c and Inc_c tilt-corrected declination and inclination. $a 95$ Fisher (1953) $95 \%$ confidence limit, $k$ Fisher (1953) concentration parameter
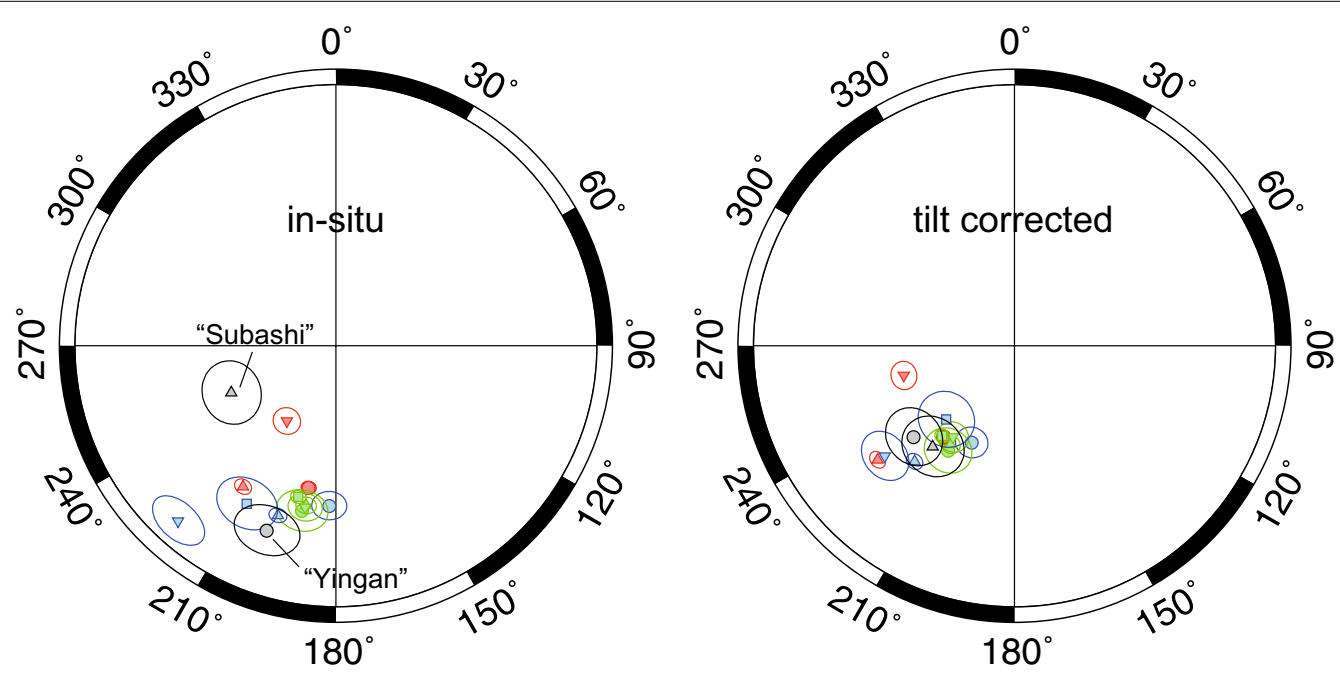

Fig. 7 Equal area plot of site-mean directions before and after tilt correction (upper hemisphere projection) with $a_{95}$ confidence ellipses. Green symbols represent flows in a directional group (see text). Red and blue symbols represent the other flows belonging to the Kaipaizileike Formation and the Kupukuziman Formation, respectively. Black circle and triangle represent section mean direction after Sharps et al. (1989) for Yingan and Subashi section, respectively

Table 3 Summary of the paleointensity results

\begin{tabular}{|c|c|c|c|c|c|c|}
\hline Specimen & Material & Paleointensity $(\mu \mathrm{T})$ & $N$ & $\beta$ & MAD & $\delta(\mathrm{CK})$ \\
\hline KP1a-x10 & Plagioclase & 17.37 & 5 & 0.04 & 8 & 4.7 \\
\hline KP1a-x12 & Plagioclase & 10.12 & 6 & 0.14 & 6.6 & 5.1 \\
\hline KP1b-x1 & Plagioclase & 7.13 & 8 & 0.06 & 7.6 & 5.1 \\
\hline KP1b-x3 & Plagioclase & 9.4 & 10 & 0.1 & 4.1 & 5.8 \\
\hline KZ2a-x4 & Plagioclase & 38.01 & 10 & 0.06 & 3.6 & 4.5 \\
\hline KZ4-X2 & Plagioclase & 16.08 & 5 & 0.08 & 2.7 & 6.1 \\
\hline KZ4-d & Whole rock & 36.39 & 7 & 0.13 & 1.5 & 2.7 \\
\hline KZ4-e & Whole rock & 44.54 & 7 & 0.1 & 1.5 & 2.8 \\
\hline
\end{tabular}

$N$ number of steps used for calculation, $\beta$ standard deviation of the linear fit in the Arai plot relative to the slope, $M A D$ maximum angular deviation of the linear directional fit, $\delta(C K)$ maximum absolute difference produced by a pTRM check, normalized by the total TRM 
a

KZ4-d

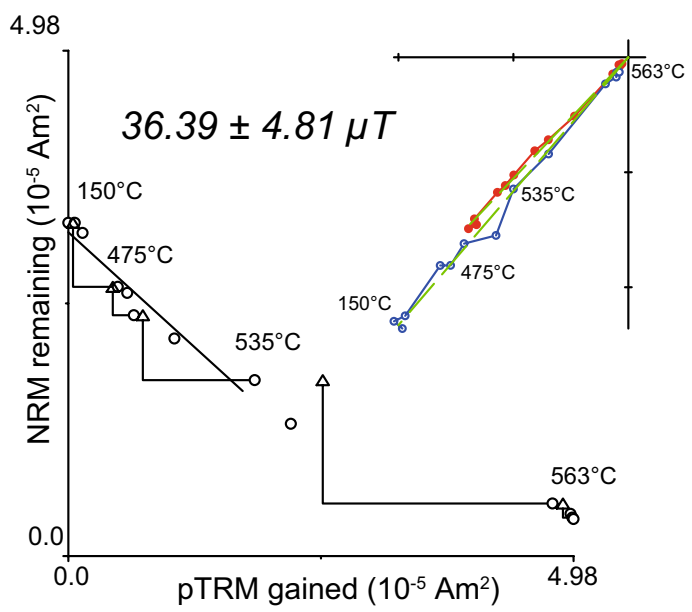

c

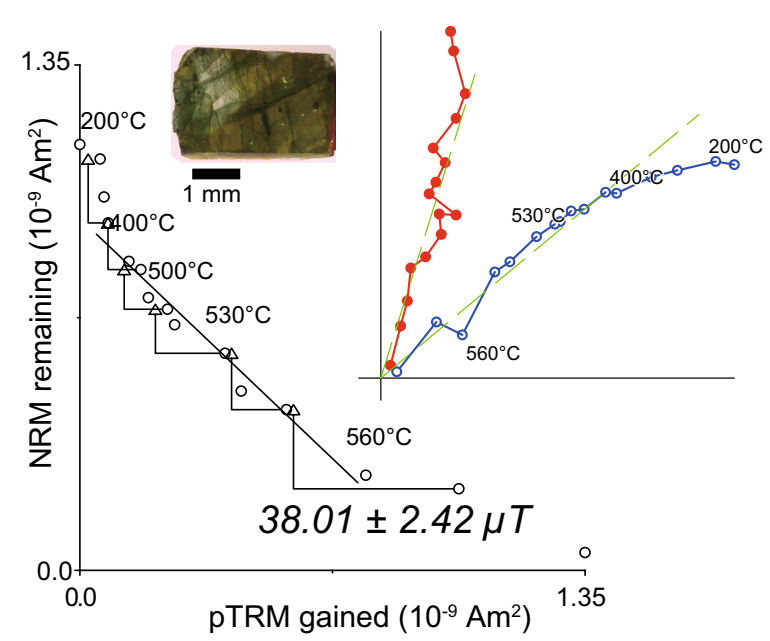

e

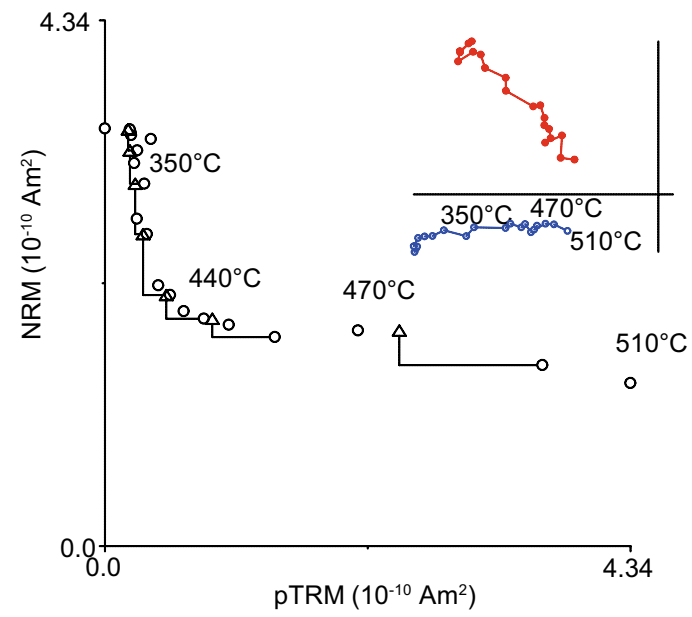

b

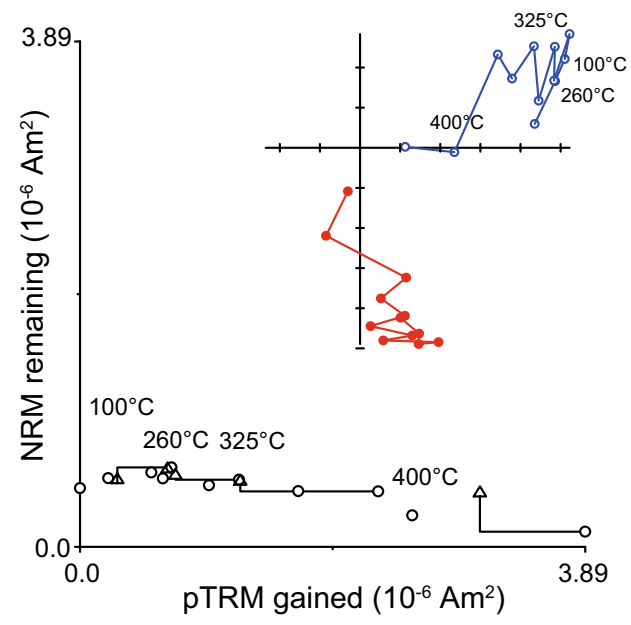

d $\quad \mathrm{KP} 1 \mathrm{a}-\mathrm{x} 10$

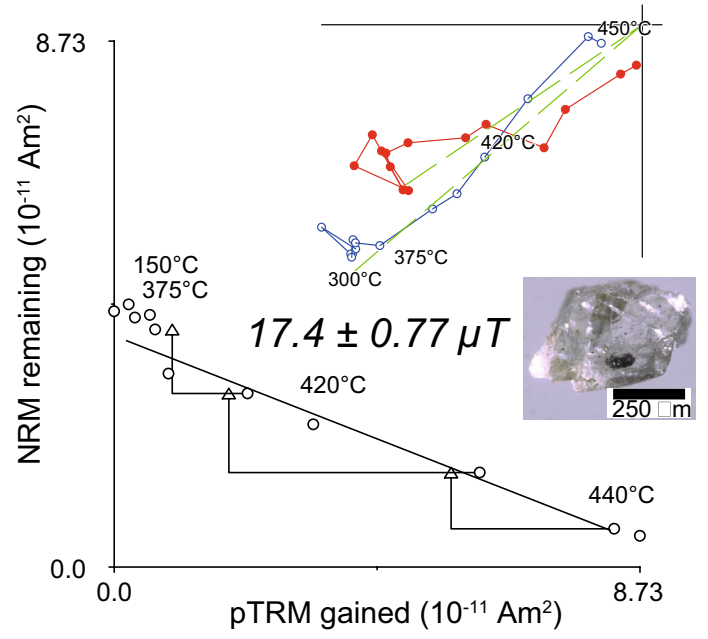

f

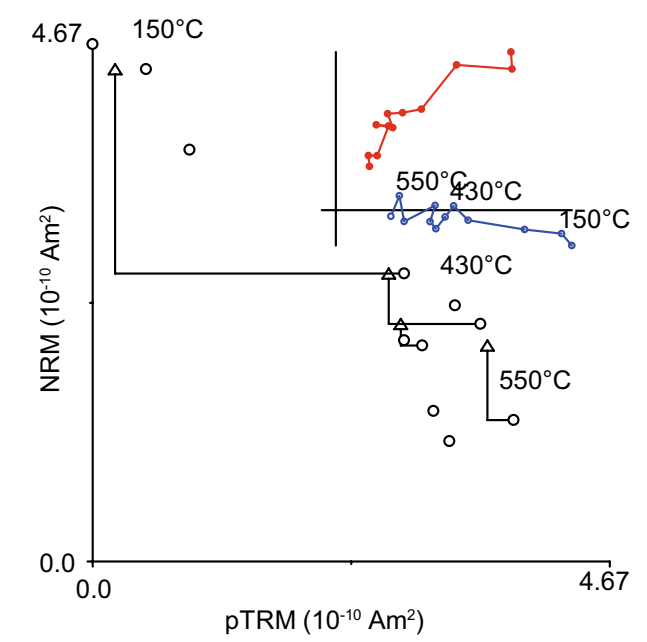


(See figure on previous page.)

Fig. 8 Representative paleointensity experiment shown on the Arai diagrams. Triangles represent the pTRM checks. Lines indicate least-squares fits to estimate paleointensity. The insets show the Z-step data on the orthogonal vector plots. Green dashed line indicates the principal component fit of the direction. Samples are unoriented relative to the geographic coordinate. a A successful result of whole-rock sample. b A failed result of whole-rock sample. $\mathbf{c}$, $\mathbf{d}$ Successful results of single plagioclase samples. e, $\mathbf{f}$ Failed results of single plagioclase samples

\section{Discussion}

\section{PSV speed during PCRS and timescale for the TLIP basalt activity}

The occurrence of a directional group spanning four flows indicates that these flows, a total of $\sim 150$-m thick, erupted quickly relative to the speed of PSV. To quantify the eruption frequency, we have to make an assumption about the PSV speed at $290 \mathrm{Ma}$, which is in the PCRS. In terms of PSV magnitude, the Cretaceous normal Superchron has been characterized by a slightly smaller variation at low latitudes compared to the previous 5 Myr (Tarduno et al. 2002; Biggin et al. 2008). A similar tendency was reported for the PCRS (Halden et al. 2009). However, for latitudes higher than $\sim 30^{\circ}$, the PSV magnitude during the PCRS is statistically indistinguishable from data for the last $5 \mathrm{Myr}$ (Franco et al. 2012). Moreover, the relationship between the PSV magnitude and the PSV speed is not clear. Musgrave and Fussell (2011) reported exceptionally high temporal resolution paleomagnetic data for PCRS from high-latitude $\left(70^{\circ}\right)$ glacial varved sediment. Although their data span only 1000 years while the PCRS lasted for $>50 \mathrm{Myr}$, the analysis of the Musgrave and Fussel (Musgrave and Fussell 2011) data reveals a PSV speed of 5-12\% century (mean: $8.0^{\circ}, 1 \sigma: 3.8^{\circ}$ ). From these observations, we tentatively assume that the PSV speed during the PCRS at mid- to high-latitudes was not grossly different from the Holocene value (2-7\% century).

Our analysis indicates that a directional group with four flows (KZ2a-KZ3a) does not record a PSV larger than $\sim 10^{\circ}$. Assuming a typical PSV speed of $5-12^{\circ} /$ century (Musgrave and Fussell 2011), the flows are estimated to have erupted within a few centuries. The directional group consists of a total of $\sim 150$ m of basalt. This is similar in thickness to the directional groups reported from the Deccan trap (Chenet et al. 2008). Note that we cannot estimate the volume flux of eruptions, as we only measure specimens from outcrops. Better stratigraphic correlation between outcrop and drill cores is necessary to quantify the TLIP eruption history.

\section{Paleointensity as a potential stratigraphic marker}

The paleointensity estimates appear to be different between the two flows in the Kaipaizileike Formation (KP1a and KP1b) and the two flows in the Kupukuziman Formation (KZ2a and KZ4). We have to emphasize that the quality of these data and the number of specimens are not sufficient to establish reliable absolute paleointensity estimates (e.g., Patterson et al. 2014). Nonetheless, a relatively similar lithology studied here may allow discussion about the relative differences among the flows. The similarity of paleointensity among the directional group identified by directional analysis (i.e., KZ2a and KZ4) supports the discussion that they erupted in a short period of time. Note that how short this period was depends on the assumption about PSV speed. In contrast, the difference between $\{K P 1 \mathrm{a}, \mathrm{KP} 1 \mathrm{~b}\}$ and $\{\mathrm{KZ} 2 \mathrm{a}$, KZ4\} represents a time gap. While we measured only two flows from each of the Kaipaizileike and Kupukuziman Formations, thick $(\sim 600 \mathrm{~m})$ siliciclastic sediment between those Formations hints that there may be a certain time gap between them. We hypothesize that the Kaipaizileike and Kupukuziman Formation may record relatively low and high paleointensity, respectively. If this is the case, the paleointensity signal could serve as a stratigraphic marker to correlate outcrop data with drill core data. Further work is necessary to confirm or reject this possibility.

\section{Conclusion}

We measured the paleomagnetic direction and paleointensity of the TLIP basaltic flows. Out of 11 flows studied, four flows revealed statistically identical paleomagnetic directions, forming a directional group. These flows are estimated to have erupted in a short time relative to the PSV. If we assume the PSV speed to be similar to the present day based on limited data, the directional group, which amounts to $\sim 150 \mathrm{~m}$ of basalt, is estimated to have erupted within the past few centuries. The flows within the directional group revealed similar paleointensity estimates, supporting the hypothesis that the eruption of these flows was relatively rapid. Rapid eruption might have resulted in a major environmental change. To evaluate fully the impact of the TLIP basalt, correlation of the outcrop data with geophysical and drill core data should be improved to evaluate the lava volume.

The paleointensity estimates are lower for the Kaipaizileike Formation than for the Kupukuziman Formation. These two formations are separated by thick siliciclastic sedimentary rocks; thus, we propose the difference reflects the secular variation of paleointensity during the PCRS. The potential paleointensity difference, 
if confirmed by further studies, may be used as a stratigraphic marker to promote correlation between outcrop and drill cores.

\section{Authors' contributions}

YU and WT contributed to the study design, field works, and data interpretation. YU conducted paleomagnetic measurements. YU wrote the paper with inputs from WT. All authors read and approved the final manuscript.

\section{Author details}

1 Department of Deep Earth Structure and Dynamics Research, Japan Agency for Marine-Earth Science and Technology, 2-15 Natsushima-cho, Yokosuka 2370061 , Japan. ${ }^{2}$ School of Earth and Space Sciences, Peking University, Beijing 100871, China.

\section{Acknowledgements}

This work was supported by JSPS KAKENHI Grant Number JP24740309 to YU and NSFC grant (No. 41272368) to WT. We thank Dr. Hirokuni Oda for the permission to use AGM in GSJ.

\section{Competing interests}

The authors declare that they have no competing interests.

Received: 24 July 2016 Accepted: 27 December 2016

Published online: 19 January 2017

\section{References}

Arai Y (1963) Secular variation in intensity of the past geomagnetic field, M.Sc. Thesis Uniersity, Tokyo

Biggin AJ, van Hinsbergen DJJ, Langereis CG, Straathof GB, Deenen MHL (2008) Geomagnetic secular variation in the Cretaceous Normal Superchron and in the Jurassic. Phys Earth Planet Inter 169:3-19

Bond DPG, Wignall PB (2014) Large igneous provinces and mass extinctions: an update. In: Keller G, Kerr AC (eds) Volcanism, impacts, and mass extinction: causes and effects. Geological society of America special paper 505. doi:10.1130/2014.2505(02)

Bryan SE, Ernst RE (2008) Revised definition of large igneous provinces (LIPs). Earth Sci Rev 86(1-4):175-202

Chen N, Dong J, Yang S, Chen J, Li Z, Ni N (2014) Restoration of geometry and emplacement mode of the Permian mafic dyke swarms in Keping and its adjacent areas of the Tarim Block. NW China Lithos 204:73-82

Chenet AL, Fluteau F, Courtillot V, Gérard M, Subbarao KV (2008) Determination of rapid Deccan eruptions across the Cretaceous-Tertiary boundary using paleomagnetic secular variation: results from a 1200-m-thick section in the Mahabaleshwar escarpment. J Geophys Res 113:B04101

Coe RS (1967) The determination of paleointensities of the earth's magnetic field with emphasis on mechanisms which could cause non-ideal behavior in Thellier's method. J Geomagn Geoelectr 19:157-179

Coe RS, Grommé CS, Mankinen EA (1978) Geomagnetic paleointensities from radiocarbon-dated lava flows on Hawaii and the question of the Pacific nondipole low. J Geophys Res 83:1740-1756

Courtillot V, Fluteau F (2014) A review of the embedded time scales of flood basalt volcanism with special emphasis on dramatically short magmatic pulses. In: Keller G, Kerr A (eds) Volcanism, impacts, and mass extinction: causes and effects. Geological society of america special paper 505. doi:10.1130/2014.2505(02)

Day R, Fuller MD, Schmidt VA (1977) Hysteresis properties of titanomagnetites: grain size and composition dependence. Phys Earth Planet Inter 13:260-267

Dodd SC, Mac Niocail C, Muxworthy AR (2015) Long duration (>4 Ma) and steady-state volcanic activity in the early Cretaceous Paraná-Etendeka large igneous province: new paleomagnetic data from Namibia. Earth Planet Sci Lett. 414:16-29

Dunlop DJ (2002) Theory and application of the Day plot $\left(M_{\mathrm{rs}} / M_{\mathrm{s}}\right.$ versus $\left.H_{c r} / H_{c}\right): 1$. Theoretical curves and tests using titanomagnetite data. J Geophys Res 107:2056
Fisher R (1953) Dispersion on a sphere. Proc R Soc A Math Phys Eng Sci 217(1130):295-305

Franco DR, Ernesto M, Ponte-Neto CF, Hinnov LA, Barquó TS, Bavris JD, Rosière CA (2012) Magnetostratigraphy and mid-paleolatitude VGP dispersion during the Permo-Carboniferous Superchron: results from Paraná Basin (Southern Brazil) rhythmites. Geophys J Int 191:993-1014

Gallet Y, Genevey A, Goff ML (2002) Three millennia of directional variation of the earth's magnetic field in western Europe as revealed by archeological artifacts. Phys Earth Planet Inter 131:81-89

Hagstrum JT, Campion DE (2002) A Holocene paleosecular variation record from ${ }^{12} \mathrm{C}$-dated volcanic rocks in western North America. J Geophys Res 107:1-14

Halden MM, Langereis CG, Biggin AJ, Dekkers MJ, Evans ME (2009) A comparison of detailed equatorial red bed records of secular variation during the Permo-Carboniferous Reversed Superchron. Geophys J Int 177:834-848

Jackson A, Jonkers ART, Walker MR (2000) Four centuries of geomagnetic secular variation from historical records. Philos Trans R Soc London A 358:957-990

Kirschvink JL (1980) The least-squares line and plane and the analysis of paleomagnetic data. Geophys J R Astron Soc. 62:699-718

Knight KB, Nomade S, Renne PR, Marzoli A, Bertran H, Youbi N (2004) The Central Atlantic magmatic provinces at the Triassic-Jurassic boundary: paleomagnetic and ${ }^{40} \mathrm{Ar} /{ }^{39} \mathrm{Ar}$ evidence from Morocco for brief, episodic volcanism, earth planet. Sci Lett. 228:143-160

Leonhardt R, Heunemann C, Krása D (2004) Analyzing absolute paleointensity determinations: acceptance criteria and the software ThellierTool4.0. Geochem Geophys Geosyst 12:Q12016

Lurcock PC, Wilson GS (2012) PuffinPlot: a versatile, user-friendly program for paleomagnetic analysis. Geochem Geophys Geosyst 13:Q06Z45. doi:10.1 029/2012GC004098

Makinen EA, Prévot M, Grommé CS, Coe RS (1985) The Steen's Mountain (Oregon) geomagnetic polarity transition: 1. Directional history, duration of episodes, and rock magnetism. J Geophys Res 90B:10393-10416

Musgrave RJ, Fussell MS (2011) Paleosecular variation during the Kiaman Superchron: a 1150 year record from glacial varves of the Seaham Formation, New South Wales. Aust J Earth Sci 58:375-389

Patterson GA, Tauxe L, Biggin AJ, Shaar R, Jonestrask LC (2014) On improving the selection of Thellier-type paleointensity data. Geochem Geophys Geosyst 15:1180-1192

Pavlov VE, Fluteau F, Veselovskiy RV, Fetisova AM, Latyshev AV (2011) Secular geomagnetic variation and volcanic pulses in the Permian-Triassic Traps of the Norilsk and Maimecha-Kotui Provinces. Izvestiya Phys Solid Earth 47:402-417

Riisager J, Riisager P, Pedersen AK (2003) Paleomagnetism of large igneous provinces: case study from west Greenland, North Atlantic igneous province. Earth Planet Sci Lett 214:409-425

Shaar R, Tauxe L, Ben-Yosef E, Kassianidou V, Lorentzen B, Feinberg JM, Levy TE (2015) Decadal-scale variation in geomagnetic field intensity from ancient Cypriot slag mounds. Geochem Geophys Geosyst 16:195-214

Sharps R, McWilliams M, Li Y, Cox A, Zhan Z, Zhai Y, Gao Z, Li Y, Li Q (1989) Lower Permian paleomagnetism of the Tarim block, northwestern China. Earth Planet Sci Lett 92:275-291

Tarduno JA, Cottrell RD, Smirnov AV (2002) The Cretaceous superchron geodynamo: observations near the tangent cylinder. Proc Natl Acad Sci 99(22):14020-14025

Tauxe L, Staudigel H (2004) Strength of the geomagnetic field in the Cretaceous Normal Superchron: new data from submarine glass of the Troodos Ophiolite. Geochem Geophys Geosyst 5:Q02H06

Thellier $E$, Thellier O (1959) Sur l'intensitè du champ magnètique terrestre dans le passè historique et gèologique. Ann Geophys 15:285-376

Tian W, Campbell IH, Allen CM, Guan P, Pan W, Chen M, Yu H, Zhu W (2010) The Tarim picrate-basalt-rhyolite suite, a Permian flood basalt from northwest China with contrasting rhyolites produced by fractional crystallization and anatexis. Contrib Miner Pet 160:407-425

Usui Y, Shibuya T, Sawaki Y, Komiya T (2015) Rock magnetism of tiny exsolved magnetite in plagioclase from a Paleoarchean granitoid in the Pilbara craton. Geochem Geophys Geosyst 16:112-125

Wei X, Xu YG, Feng YX, Zhao JX (2014) Plume-lithosphere interaction in the generation of the Tarim large igneous province, NW China: geochronological and geochemical constraints. Am J Sci 314:314-356 
Wignall PB (2001) Large igneous provinces and mass extinctions. Earth Sci Rev $53: 1-33$

Yang SF, Chen HL, Ji DW, Li ZL, Dong CW, Jia CZ, Weri GQ (2005) Geological process of early to middle Permian magmatism in Tarim Basin and its geodynamic significance. Geol J China Univ 11:504-511 (in Chinese with English abstract)
Yang S, Li Z, Chen H, Dong C, Yu X (2006) Permian large volume basalts in Tarim basin. Available via June 2006 LIP of the month. http://largeigneousprovinces.org/06jun. Accessed 5 Jan 2017

Yu X, Yang SF, Chen HL, Chen ZQ, Li ZL, Batt GE, Li YQ (2011) Permian flood basalts from the Tarim Basin Northwest China: SHRIMP zircon U-Pb dating and geochemical characteristics. Gondwana Res. 20:485-497

\section{Submit your manuscript to a SpringerOpen ${ }^{\odot}$ journal and benefit from:}

- Convenient online submission

- Rigorous peer review

- Immediate publication on acceptance

- Open access: articles freely available online

- High visibility within the field

- Retaining the copyright to your article 